\title{
BANK LOAN SUPPLY AND MONETARY POLICY TRANSMISSION IN GERMANY: \\ AN ASSESSMENT BASED ON MATCHING IMPULSE RESPONSES
}

\author{
OLIVER HUELSEWIG \\ ERIC MAYER \\ TIMO WOLLMERSHAEUSER
}

CESIFO WORKING PAPER NO. 1380

CATEGORY 6: MONETARY POLICY AND INTERNATIONAL FINANCE

JANUARY 2005
An electronic version of the paper may be downloaded
- from the SSRN website:
www.SSRN.com
- from the CESifo website:
www.CESifo.de




\title{
BANK LOAN SUPPLY AND MONETARY POLICY TRANSMISSION IN GERMANY: AN ASSESSMENT BASED ON MATCHING IMPULSE RESPONSES
}

\begin{abstract}
This paper addresses the credit channel in Germany by using aggregate data. We present a stylized model of the banking firm in which banks decide on their loan supply in light of uncertainty about the future course of monetary policy. Applying a vector error correction model (VECM), we estimate the response of bank loans after a monetary policy shock taking into account the reaction of the output level and the loan rate. We estimate our model to characterize the response of bank loans by matching the theoretical impulse responses with the empirical impulse responses to a monetary policy shock. Evidence in support of the credit channel can be reported.
\end{abstract}

JEL Code: E44, E51.

Keywords: monetary policy transmission, credit channel, loan supply, loan demand, minimum distance estimation.

\author{
Oliver Huelsewig \\ Ifo Institute for Economic Research \\ at the University of Munich \\ Poschingerstr. 5 \\ 81679 Munich \\ Germany \\ Huelsewig@ifo.de
}

\author{
Eric Mayer \\ University of Wuerzburg \\ Department of Economics \\ Sanderring 2 \\ 97070 Wuerzburg \\ Germany \\ eric.mayer@mail.uni-wuerzburg.de
}

\author{
Timo Wollmershaeuser \\ Ifo Institute for Economic Research \\ at the University of Munich \\ Poschingerstr. 5 \\ 81679 Munich \\ Germany \\ Wollmershaeuser@ifo.de
}

We are grateful to Gebhard Flaig, David VanHoose and Charles Goodhart for helpful comments and suggestions on an earlier version of this paper. 


\section{Introduction}

The credit channel assigns banks a pivotal role in the transmission of monetary policy, which stems from the notion that financial markets are characterized by imperfections. ${ }^{1}$ Banks are special in extending credit to borrowers - that cannot access other types of credit - because of their expertise in mitigating financial frictions. If banks adjust their loan supply following a change in the stance of monetary policy, this has a bearing on real activity, since some borrowers have to rearrange their expenditure decisions. ${ }^{2}$

As Bernanke and Gertler (1995) and Hubbard (1995) point out, the credit channel is working in addition to the interest rate channel, according to which monetary policy affects the level of investment and consumer spending by inducing changes in the cost of capital and yield on savings. Although, the credit channel and the interest rate channel diverge in assessing the relevance of financial considerations, they are deemed complementary, with the implication that monetary policy can be effective through these transmission channels simultaneously.

In the spirit of Bernanke and Blinder (1992), a number of studies based on vectorautoregression (VAR) analysis have examined whether the credit channel is operating alongside the interest rate channel by using aggregate data. Many studies have shown that bank loans decline after a monetary policy shock, but these findings are plagued by a severe identification problem, as it remains unclear whether the drop is driven by loan supply or loan demand effects. While the credit channel emphasizes a shift in loan supply, the interest rate channel stresses a shift in loan demand, which stems from a policy-induced decline in real activity. Distinguishing between these predictions is a difficult task, as "it is not possible using reduced-form estimates based on aggregate data alone, to identify whether bank balance sheet contractions are caused by shifts in loan supply or loan demand" (Cecchetti, 1995, p. 92).

In light of this ambiguity, several studies have explored heterogeneity across agents by moving from aggregate data to disaggregated data. For the U.S., Gertler and Gilchrist (1993), Gilchrist and Zakrajsek (1995) and Oliner and Rudebusch (1995) use panel data of a large number of business firms. From this research it appears that firms of different size encounter different financial constraints after a monetary tightening. Kashyap and Stein (2000) investigate panel data at the individual bank level. They observe that monetary policy particularly affects the

\footnotetext{
${ }^{1}$ See Bernanke and Gertler (1995), Cecchetti (1995) or Hubbard (1995) for a survey of the credit channel of monetary policy transmission.

${ }^{2}$ This idea centers on the assumption that some borrowers - in particular small and mediumsized firms - cannot issue corporate bonds at reconcilable terms because of information problems or high costs associated with launching debt securities. Banks as financial intermediaries specialize in gathering and distilling information, which enables them to make loans to these borrowers at more favorable terms.
} 
lending behavior of small banks with less liquid balance sheets. Kishan and Opiela (2000) report a similar finding by approximating bank lending activities on the basis of bank size and bank capital.

So far, much work on the credit channel in Germany - implemented by Barran, Coudert, and Mojon (1997), De Bondt (2000), Ehrmann (2004), Ehrmann and Worms (2004), Holtemöller (2003), Hülsewig, Winker, and Worms (2004), Kakes and Sturm (2002), Küppers (2001), Von Kalckreuth (2003) and Worms (2003) - has employed aggregate and disaggregated data but reported contrary results. While some of these studies find evidence in support of the credit channel, others conclude that the credit channel is ineffective. The vagueness in the results reflects in part the difficulty in separating the loan supply effects from the loan demand effects that follow a monetary contraction.

This paper addresses the credit channel in Germany by using aggregate data. We present a stylized model of the banking firm, which specifies the loan supply decision of banks in light of uncertainty about the future course of monetary policy. Applying a vector error correction model (VECM), we estimate the response of bank loans to a monetary policy shock taking into account the reaction of the output level and the loan rate. We use our model as a guide to characterize the response of bank loans - i.e. to decompose the adjustment of bank loans into the parts that can be attributed to loan supply and loan demand - by matching the theoretical impulse responses with the empirical impulse responses to a monetary policy shock. In this vein, the identification problem inherent in aggregate data is explicitly addressed. ${ }^{3}$

Our findings suggest that the credit channel is operating alongside the interest rate channel. Banks decrease their loan supply with an expected drop in their credit margin after a monetary policy shock, while loan demand declines with a drop in the output level and a rise in the loan rate. The decrease in loan supply occurs instantly and bottoms out gradually. The decrease in loan demand proceeds by degrees and continues persistently.

The remainder of this paper is organized as follows. Section 2 presents our model of the banking firm, which establishes the basis for our testing. Section 3 sets out the empirical results, which are derived by adopting a two-step procedure. First, we estimate a VECM to generate impulse responses to a monetary policy shock. Second, we estimate our model by using a limited distance estimation, which matches the theoretical impulse responses with the empirical impulse responses. Section 4 provides concluding remarks.

\footnotetext{
${ }^{3}$ To our knowledge separating loan supply effects from loan demand effects by matching impulse responses has not yet been proposed in the literature.
} 


\section{A Model of the Banking Firm}

We base our analysis of the credit channel on a stylized model of the banking firm, in which banks decide on their loan supply when future monetary policy is uncertain. The model refers to Cosimano (1988) and Sargent (1979). Similar approaches have been developed by Bofinger (2001), Elyasiani, Kopecky, and van Hoose (1995) and Mitusch and Nautz (2001).

\subsection{Structure of the Model}

Consider a banking system with many identical banks that act as price takers. Banks grant loans to nonbanks $\left(L_{t}\right)$, which they finance with deposits $\left(D_{t}\right)$ and central bank credits $\left(B_{t}\right)$ after subtracting required reserves $\left(R_{t}\right)$. Each bank takes the loan rate $\left(r_{t}^{L}\right)$ and the deposit rate $\left(r_{t}^{D}\right)$ as given. The central bank is assumed to administer the policy rate $\left(r_{t}^{M}\right)$ that determines the interest rate on the interbank money market. ${ }^{4}$

For a single bank $i$, profit at time $t+j$ is given by:

$$
\pi_{t+j}^{i}=r_{t+j}^{L} L_{t+j}^{i}-r_{t+j}^{D} D_{t+j}^{i}-r_{t+j}^{M} B_{t+j}^{i}-C_{t+j},
$$

where:

$$
\begin{aligned}
\pi_{t+j}^{i}= & \text { profit at time } t+j, \\
L_{t+j}^{i}= & \text { loans at time } t+j \text { at rate } r_{t+j}^{L}, \\
D_{t+j}^{i}= & \text { deposits at time } t+j \text { at rate } r_{t+j}^{D}, \\
B_{t+j}^{i}= & \text { net position on the interbank money market } \\
& \text { at time } t+j \text { at rate } r_{t+j}^{M}, \\
C_{t+j}= & \text { costs of evaluating and adjusting the stock } \\
& \text { of loans at time } t+j .
\end{aligned}
$$

Note that equation ( 1 ) is defined for $j=0,1,2, \ldots$.

Bank profit matches the difference between the revenues and costs in the credit business. Besides interest costs, the bank faces costs associated with adjusting the loan portfolio $\left(C_{t+j}\right)$, which are represented by (see e.g. Cosimano (1988)):

$$
C_{t+j}=(a / 2)\left(L_{t+j}^{i}-L_{t+j-1}^{i}\right)^{2},
$$

where $(a)$ is a positive constant. The costs of adjusting the loan portfolio can be thought of as reflecting the allocation of resources necessary to evaluate the

\footnotetext{
${ }^{4}$ Notice that throughout the paper we presume that monetary policy is implemented by the central bank in the form of an interest rate targeting procedure.
} 
creditworthiness of customers and to monitor loans during the duration. If the bank realizes a change in the size of its loan portfolio, this requires to reshuffle the amount of resources devoted to these activities. Assume the banking sector comprises $(n)$ banks with identical cost functions.

A single bank seeks to maximize the expected present value of its profit flow:

$$
V_{t}=E_{t} \sum_{j=0}^{\infty} \beta^{j} \pi_{t+j}^{i}
$$

where $\left(E_{t}\right)$ is the rational expectation operator conditioned on the information set $\left(I_{t}\right)$ disposable at time $t$, and $(\beta)$ is a discount factor $(0<\beta<1)$. Let the information set $\left(I_{t}\right)$ include the past values of all variables and the present values of all interest rates, i.e. $E_{t}\left(x_{t+j}\right) \equiv E\left(x_{t+j} \mid I_{t}\right)$.

The maximization is subject to the balance sheet constraint:

$$
L_{t+j}^{i}+R_{t+j}^{i}=D_{t+j}^{i}+B_{t+j}^{i},
$$

where minimum reserves $\left(R_{t+j}^{i}\right)$ are determined by: $R_{t+j}^{i}=d D_{t+j}^{i}$, with $(d)$ denoting the minimum reserve ratio $(0<d<1)$. For a single bank the level of deposits $\left(D_{t+j}^{i}\right)$ is assumed to be exogenously given (see e.g. Baltensperger (1980); Klein (1971)). Depending on stochastic flows, the bank adjusts its net position on the interbank money market $\left(B_{t+j}^{i}\right)$ to meet the balance sheet constraint. ${ }^{5}$ The deposit rate $\left(r_{t+j}^{D}\right)$ is presumed to adjust to the interbank money market rate $\left(r_{t+j}^{M}\right)$ in consideration of the minimum reserve ratio due to arbitrage conditions (Freixas and Rochet, 1997, p. 57).

\section{$2.2 \quad$ Deriving Optimal Loan Supply}

A single bank maximizes the expected present value of its profit flow by choosing the optimal path of loans subject to the balance sheet constraint and conditional on the set of available information.

Bank $i$ 's optimal loan supply is given by: ${ }^{6}$

$$
L_{t+j}^{i}=L_{t+j-1}^{i}+a^{-1} \sum_{s=0}^{\infty} \beta^{s} E_{t+j}\left(r_{t+j+s}^{L}-r_{t+j+s}^{M}\right), \quad j=0,1,2, \ldots,
$$

which raises with an expected increase in the loan rate and falls with an expected increase in the policy rate. If the cost of adjustment parameter for loans $(a)$

\footnotetext{
${ }^{5}$ Hence, for a single bank $\left(B_{t+j}^{i}\right)$ can either be positive or negative depending on whether the bank borrows or lends on net at the prevailing interbank money market rate.

${ }^{6}$ The procedure used for deriving optimal loan supply is taken from Sargent (1979). See Appendix A for details.
} 
increases, this requires a higher expected credit margin in order to maintain a specific level of lending.

Notice that optimal loan supply is derived from the first order-condition:

$$
r_{t+j}^{L}-a\left(L_{t+j}^{i}-L_{t+j-1}^{i}\right)+a \beta E_{t+j}\left(L_{t+j+1}^{i}-L_{t+j}^{i}\right)-r_{t+j}^{M}=0,
$$

which shows that the optimal loan level is characterized by the equation of the spread between the loan rate and the policy rate and the marginal costs of evaluating and adjusting the loan portfolio. The first-order condition is valid for $j=0,1,2, \ldots$; when $j=0$, the variables refer to the presently observed and expected values.

\subsection{Loan Market Repercussions}

Our model incorporates the assumption of a single and homogeneous loan market. Aggregate loan supply of the banking sector satisfies (here, evaluated for $j=0$ ):

$$
L_{t}=L_{t-1}+n a^{-1} \sum_{s=0}^{\infty} \beta^{s} E_{t}\left(r_{t+s}^{L}-r_{t+s}^{M}\right),
$$

which is the sum of the supplies of the $(n)$ identical banks that refer to the currently observed and expected values.

Aggregate loan demand is assumed to be given by:

$$
L_{t}=b_{1} y_{t}-b_{2} r_{t}^{L},
$$

where $\left(y_{t}\right)$ is the output level and $\left(b_{1}\right)$ and $\left(b_{2}\right)$ are positive parameters. ${ }^{7}$ The demand for loans raises with an increase in the output level and falls with an increase in the loan rate. The parameters $\left(b_{1}\right)$ and $\left(b_{2}\right)$ denote the income elasticity and the interest elasticity of aggregate loan demand.

The equilibrium in the loan market is characterized by the equilibrium loan level and the equilibrium loan rate. ${ }^{8}$ The equilibrium loan volume that maximizes the banks' present value is (for $j=0$ ):

$$
L_{t}=\lambda_{1} L_{t-1}+\lambda_{1} n a^{-1} \sum_{s=0}^{\infty} \lambda_{2}^{-s} E_{t}\left(B_{1} y_{t+s}-r_{t+s}^{M}\right),
$$

where $\lambda_{1}$ and $\lambda_{2}$ are positive characteristic roots, with $\lambda_{1}<1<1 / \beta<\lambda_{2}$, and $B_{1}=b_{1} / b_{2}$. The equilibrium loan volume increases with an expected future

\footnotetext{
${ }^{7}$ Modelling loan demand in dependency of the output level and the loan rate is commonly accepted. See Calza, Gartner, and Sousa (2003), Hülsewig, Winker, and Worms (2004) or Kakes (2000) - among others - for empirical support.

${ }^{8}$ Since the credit channel does not imply credit rationing, we assume - for the sake of simplicity - that the loan market clears by price (see e.g. Gertler and Gilchrist (1993)).
} 
increase in the output level and decreases with an expected future increase in the policy rate. Substituting the equilibrium loan level (9) into the loan demand equation (8) yields the equilibrium loan rate:

$$
r_{t}^{L}=B_{1} y_{t}-B_{2} \lambda_{1} L_{t-1}-B_{2} \lambda_{1} n a^{-1} \sum_{s=0}^{\infty} \lambda_{2}^{-s} E_{t}\left(B_{1} y_{t+s}-r_{t+s}^{M}\right),
$$

where $B_{2}=1 / b_{2}$. The loan rate raises with an expected increase in policy rate and falls with an expected increase in the output level.

\subsection{Implications for Monetary Policy Transmission}

Our stylized model implies that banks decide on their loan supply in light of uncertainty about the future course of monetary policy. Loan supply by the banks declines with an expected fall in the credit margin after a monetary tightening, but since the adjustment in the loan level is sluggish, the effects of monetary disturbances are only passed on gradually. Since this suggests that banks are not neutral conveyors of monetary policy - as predicted by the credit channel this is equivalent to the notion that bank behavior can play a meaningful role in the propagation of monetary policy actions. We explore this prediction in the following section by assessing impulse responses to a monetary policy shock.

\section{Empirical Results}

As in Rotemberg and Woodford (1998) and Christiano, Eichenbaum, and Evans (2004), we estimate our model to evaluate the adjustment of bank loans to a monetary policy shock by using a two-step procedure. In the first step, we estimate a VECM to derive empirical impulse responses. In the second step, we estimate the model by matching the theoretical impulse responses with the empirical impulse responses. The reaction of loan supply and loan demand to a monetary policy shock is determined on the basis of the estimated model parameters.

\subsection{Empirical Impulse Responses}

Following Johansen (1995) and Johansen and Juselius (1990), we employ a vector error correction model (VECM) of the form:

$$
\Delta Z_{t}=\Pi Z_{t-1}+\sum_{k=1}^{n-1} \Gamma_{k} \Delta Z_{t-k}+\Phi D_{t}+\varepsilon_{t}
$$

where $Z_{t}$ is a vector of endogenous variables, which are integrated of order one, i.e. $I(1), D_{t}$ is a vector of constant terms and $\varepsilon_{t}$ is a vector of error terms that 
are assumed to be white noise. The variable vector $Z_{t}$ comprises four variables:

$$
Z_{t}=\left(\mathrm{GDP}_{t}, r_{t}^{M}, \mathrm{LOANS}_{t}, r_{t}^{L}\right)^{\prime}
$$

where GDP stands for real output, $r^{M}$ for the policy-controlled short-term rate, LOANS for real aggregate bank loans and $r^{L}$ for the loan rate. ${ }^{9}$ Loan supply by the banks should depend on the credit margin, i.e. the spread between $r^{L}$ and $r^{M}$, while loan demand should depend on real output and the loan rate. The sample period starts in 1991Q1, after the German unification, and ends in 2003Q2. ${ }^{10}$ GDP and LOANS are in logs and $r^{M}$ and $r^{L}$ are in decimals. The vector $D_{t}$ contains an unrestricted constant and centered seasonal dummies. The lag length is set to $n=3$, which ensures that the error terms are free of autocorrelation and normally distributed.

Testing for cointegration, Table 1 reports the trace test statistic. Critical values are taken from Mackinnon, Haug, and Michelis (1999), which have been derived in response surface regressions based on simulation experiments. The

Table 1: Cointegration Test

\begin{tabular}{rcc}
\hline \hline Rank & $\begin{array}{c}\text { Trace } \\
\text { Statistic }\end{array}$ & $\begin{array}{c}\text { Critical Values* } \\
\text { 95\% Level }\end{array}$ \\
\hline 0 & 62.09 & 49.64 \\
$\leq 1$ & 33.96 & 31.88 \\
$\leq 2$ & 15.80 & 18.11 \\
$\leq 3$ & 4.91 & 8.19 \\
\hline \hline
\end{tabular}

Notes: *Mackinnon, Haug, and Michelis (1999), Table 4, Case III.

outcome of the trace test suggests that two cointegration vectors span the cointegration space. Table 2 documents multivariate test statistics, which show that the model is statistically well-specified.

Based on the VECM specification with the two cointegration vectors, we generate impulse responses of the variables in $Z_{t}$ to a monetary policy shock, which is identified by imposing a triangular orthogonalization. The ordering of the variables implies that an innovation in the short-term rate affects real output with

\footnotetext{
${ }^{9}$ See Appendix B for a description of the variables used in the analysis. The results of unit root tests show that all variables are integrated of order one, i.e. $I(1)$, which implies that the cointegration approach should be applied. The unit root rests are not reported here but are available from the authors upon request.

${ }^{10}$ Notice that the end of our sample period is determined by the switch to the new MFI interest rate statistics of the European Central Bank (ECB), which entails a structural break in the data. See Deutsche Bundesbank (2004) for details.
} 
Table 2: Tests for Misspecification

\begin{tabular}{rrrr}
\hline \hline & Test & Statistic & p-value \\
\hline Autocorrelation: & $\mathrm{LM}(1)$ & $\chi^{2}(16)=15.76$ & 0.47 \\
& $\mathrm{LM}(4)$ & $\chi^{2}(16)=13.20$ & 0.66 \\
Normality: & & $\chi^{2}(8)=10.30$ & 0.24 \\
\hline \hline
\end{tabular}

a lag of one quarter, while the loan volume and the loan rate are affected within the same quarter. Figure 1 displays the impulse responses of the variables after a monetary policy shock, which is reflected by a one-standard-deviation shock to the short-term rate. The simulation horizon covers 20 quarters. The solid lines denote impulse responses. The dotted lines are $95 \%$ error bounds based on asymptotic calculation. ${ }^{11}$

Following a monetary policy shock, bank loans decline gradually. This corroborates the results of De Bondt (2000), Holtemöller (2003) and Hülsewig, Winker, and Worms (2004), who investigate the response of aggregate bank lending in Germany in a similar framework using monthly and quarterly data. The drop in bank loans continues for around sixteen quarters until it breaks off. The output level rises in the first two quarters and then declines persistently. ${ }^{12}$ The loan rate and the short-term rate increase for about four quarters and decrease afterwards. The loan rate follows a similar pattern as the short-term rate, but generally remains on a lower level.

As Bernanke and Gertler (1995) and Cecchetti (1995) point out, the decline in bank loans after a monetary tightening is consistent with the credit channel, but since the adjustment can be interpreted as being induced by loan supply and loan demand, clear predictions are difficult to establish. For an insight, we estimate our model in an attempt to reveal the reaction of loan supply and loan demand by adopting a minimum distance estimation, which matches the theoretical impulse responses with the empirical impulse responses to a monetary policy shock. Before we present the results, we briefly discuss the methodology applied.

\footnotetext{
${ }^{11}$ For each variable the horizontal axis shows the number of quarters after the monetary policy shock has been initialized. The vertical axis measures the response of the relevant variables. In case of LOANS and GDP a value of 0.001 corresponds to a 0.1 percent change of the baseline value, while in case of the interest rates a value of 0.1 corresponds to a change of 10 basis points.

${ }^{12}$ The primary reaction of the output level after the monetary policy shock is surprising. The shift in GDP - which is also documented for Germany by Ehrmann and Worms (2004) and Mojon and Peersman (2003) - is possibly related to the structural distortions in the data that emerge right after the German reunification.
} 
Figure 1: Empirical Impulse Responses
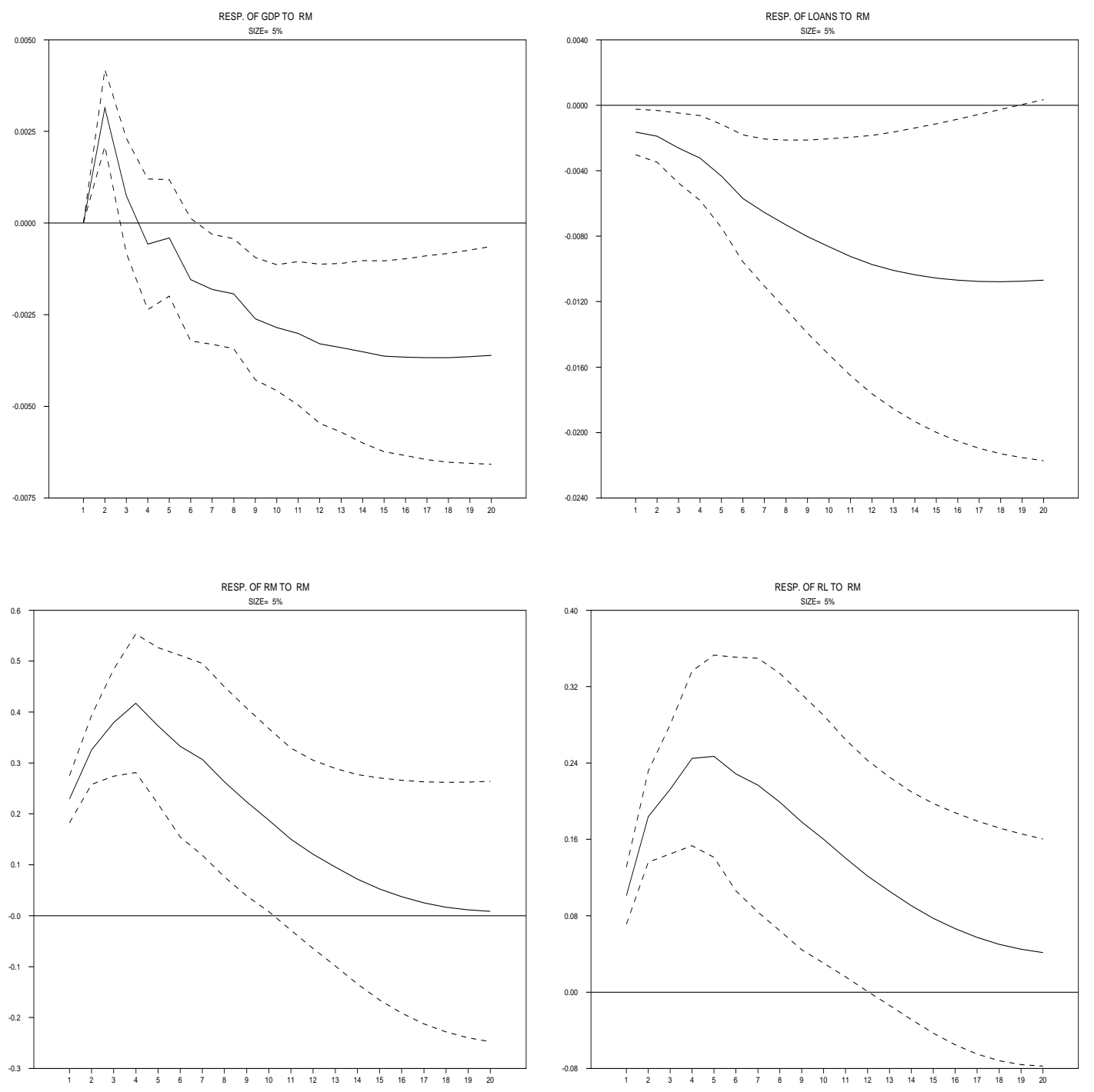


\subsection{Methodology}

The estimation of our model is based on the following state space representation:

$$
A_{0} X_{t+1}=A_{1} X_{t}+v_{t+1}
$$

where $X_{t}$ is the state vector, which is composed of a vector $X_{1, t}$ of backwardlooking variables and a vector $X_{2, t}$ of forward-looking variables, $A_{0}$ and $A_{1}$ are coefficient matrices and $v_{t+1}$ is a vector of shocks:

$$
A_{0}\left[\begin{array}{c}
X_{1, t+1} \\
E_{t} X_{2, t+1}
\end{array}\right]=A_{1}\left[\begin{array}{c}
X_{1, t} \\
X_{2, t}
\end{array}\right]+\left[\begin{array}{c}
v_{1, t+1} \\
0
\end{array}\right] .
$$

The state space representation comprises the equations:

$$
\begin{gathered}
L_{t}=\psi^{-1} \beta E_{t} L_{t+1}+\psi^{-1} L_{t-1}+B_{1} n a^{-1} \psi^{-1} y_{t}-n a^{-1} \psi^{-1} r_{t}^{M} \\
r_{t}^{L}=B_{1} y_{t}-B_{2} L_{t} \\
y_{t+1}=\gamma_{1} y_{t}+\gamma_{2} r_{t}^{L}+\gamma_{3} r_{t-1}^{L} \\
r_{t+1}^{M}=\delta_{1} r_{t}^{M}+\delta_{2} r_{t-1}^{M}+\eta_{t+1},
\end{gathered}
$$

where $\psi \equiv\left(\beta+n a^{-1} B_{2}+1\right), B_{1}=b_{1} / b_{2}$ and $B_{2}=1 / b_{2}$. The first two equations are derived from the model and specify the evolution of the loan volume and the loan rate. ${ }^{13}$ The last two equations characterize the development of the output level and the short-term rate. The output level is assumed to depend on its own lagged value and the lagged loan rate, while the short-term rate is supposed to depend on its own lagged values. The monetary policy shock is reflected by the shock term $\eta_{t+1}$. Summarizing these equations in matrix form yields:

$$
\begin{gathered}
X_{1, t}=\left[\begin{array}{c}
y_{t} \\
r_{t}^{M} \\
r_{t-1}^{M} \\
r_{t-1}^{L} \\
L_{t-1}^{L}
\end{array}\right], X_{2, t}=\left[L_{t}\right], A_{0}=\left[\begin{array}{cccccc}
1 & 0 & 0 & 0 & 0 & 0 \\
0 & 1 & 0 & 0 & 0 & 0 \\
0 & 0 & 1 & 0 & 0 & 0 \\
0 & 0 & 0 & 1 & 0 & 0 \\
0 & 0 & 0 & 0 & 1 & 0 \\
0 & 0 & 0 & 0 & 0 & \beta \psi^{-1}
\end{array}\right], v_{1, t+1}=\left[\begin{array}{c}
0 \\
\eta_{t+1} \\
0 \\
0 \\
0
\end{array}\right] \\
A_{1}=\left[\begin{array}{cccccc}
\gamma_{1}+B 1 \gamma_{2} & 0 & 0 & \gamma_{3} & 0 & -B_{2} \gamma_{2} \\
0 & \delta_{1} & \delta_{2} & 0 & 0 & 0 \\
0 & 1 & 0 & 0 & 0 & 0 \\
B_{1} & 0 & 0 & 0 & 0 & -B_{2} \\
0 & 0 & 0 & 0 & 0 & 1 \\
-B_{1} n a^{-1} \psi^{-1} & n a^{-1} \psi^{-1} & 0 & 0 & -\psi^{-1} & 1
\end{array}\right]
\end{gathered}
$$

${ }^{13}$ The identity of the equations (13) and (9) is shown in Appendix A.2. 
The closed loop dynamics of the model, which serves as a starting point to generate impulse responses, are given by:

$$
\begin{aligned}
X_{1, t+1} & =\left(A_{11}+A_{12} C\right) X_{1, t}+v_{1, t+1} \\
X_{2, t} & =C X_{1, t},
\end{aligned}
$$

where $A_{11}$ and $A_{12}$ are sub-matrices of $A=A_{0}^{-1} A_{1}$, which have been partitioned conformably with $X_{1, t}$ and $X_{2, t} \cdot{ }^{14}$ Using the algorithms as described in Söderlind (1999), the matrix $C$ is determined numerically.

For the matching of impulse responses, we estimate the set of parameters:

$$
\xi \equiv\left(b_{1}, b_{2}, n a^{-1}, \delta_{1}, \delta_{2}, \gamma_{1}, \gamma_{2}, \gamma_{3}\right)
$$

by minimizing a measure of distance between the theoretical impulse responses and the empirical impulse responses. The discount factor is calibrated to: $\beta=$ 0.99. The optimal estimator of $\xi$ minimizes the corresponding distance measure $J^{\text {opt }}(\xi)$ (see e.g. Christiano, Eichenbaum, and Evans (2004)):

$$
J=\min _{\xi}(\hat{\Psi}-\Psi(\xi))^{\prime} V^{-1}(\hat{\Psi}-\Psi(\xi))
$$

where $\hat{\Psi}$ denote the empirical impulse responses, $\Psi(\xi)$ describe the mapping from $\xi$ to the theoretical impulse responses and $V$ is the weighting matrix with the variances of $\hat{\Psi}$ on the diagonal. ${ }^{15}$ The minimization of the distance implies that those point estimates with a smaller standard deviation are given a higher priority.

\subsection{Minimum Distance Estimation}

In estimating our model, we aim at evaluating the adjustment of bank loans to a monetary policy shock. Figure 2 displays the impulse responses together with the error bounds. The theoretical responses conform quite closely with the empirical responses and fall generally - except for the primary shift in GDP - within the confidence interval. Following a monetary policy shock, bank loans decline by degrees. The output level rises slightly and then falls. The loan rate and shortterm rate increase initially and decrease afterwards.

Table 3 summarizes the estimated set of parameters $\hat{\xi}$ that minimize the distance measure. The parameter for the degree of stickiness $n a^{-1}$ is 0.001 . The

\footnotetext{
${ }^{14}$ Notice that $A_{0}^{-1}\left[\begin{array}{c}v_{1, t+1} \\ 0\end{array}\right]=\left[\begin{array}{c}v_{1, t+1} \\ 0\end{array}\right]$ since $A_{0}$ is block diagonal with an identity matrix as its upper left block and the lower block of the shock vector is zero.

${ }^{15}$ If $\xi$ is normally distributed, then $J$ has a $\chi^{2}$-distribution with $N-m$ degrees of freedom, where $N$ is the number of observations on the impulse responses and $m$ is the number of coefficients (see e.g. Smets and Wouters (2002)).
} 
Figure 2: Theoretical Impulse Responses
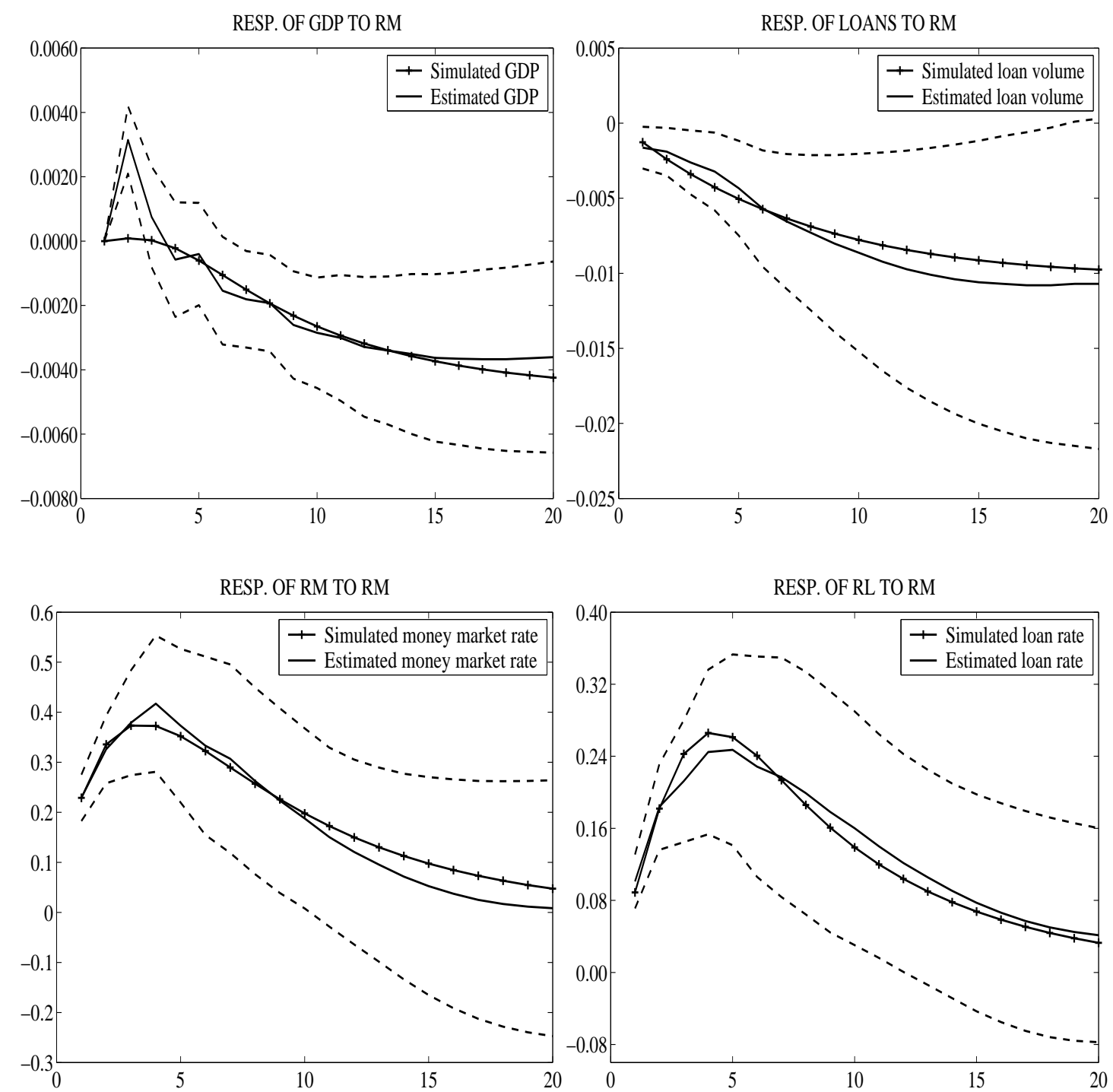
Table 3: Parameter Estimates

\begin{tabular}{ccc}
\hline \hline Parameter & Estimate & Standard Error \\
\hline$b_{1}$ & 2.1887 & 0.2474 \\
$b_{2}$ & 0.0142 & 0.0013 \\
$n a^{-1}$ & 0.0010 & 0.0001 \\
$\delta_{1}$ & 1.4665 & 0.0299 \\
$\delta_{2}$ & -0.5204 & 0.0310 \\
$\gamma_{1}$ & 0.9985 & 0.0161 \\
$\gamma_{2}$ & 0.0009 & 0.0004 \\
$\gamma_{3}$ & -0.0026 & 0.0005 \\
\hline \hline
\end{tabular}

Notes: The value function is 42.08 with a probability of 0.99 . The probability is calculated by using a Chi-Squared distribution with 72 degrees of freedom. The standard errors are calculated as the square root of the diagonal elements of the inverted Hessian matrix resulting from the optimization of the value function.

income elasticity $b_{1}$ and the interest elasticity $b_{2}$ are 2.19 and 0.014 , which is in line with other reported elasticities that range between 1.1-2.5 and 0.01-0.60 (see e.g. Calza, Gartner, and Sousa (2003), Calza, Manrique, and Sousa (2003), Fase (1995) Hülsewig, Winker, and Worms (2004) and Kakes (2000)). ${ }^{16}$

Our model implies that the adjustment of bank loans is determined jointly by the response of loan supply and loan demand to a monetary policy shock. Recall that loan supply depends on the expected credit margin:

$$
L_{t}=L_{t-1}+n a^{-1} \sum_{s=0}^{T} \beta^{s} E_{t}\left(r_{t+s}^{L}-r_{t+s}^{M}\right),
$$

while loan demand depends on the output level and the loan rate:

$$
L_{t}=b_{1} y_{t}-b_{2} r_{t}^{L} .
$$

Figure 3 displays the development of the components that drive loan supply and loan demand, which are calculated on the basis of the estimated and calibrated model parameters. ${ }^{17}$

\footnotetext{
${ }^{16}$ The divergence in the estimated elasticities of loan demand might result from using different types of loan aggregates, in particular different categories and different maturities, which implies that it might be difficult to find a robust benchmark within these ranges. According to Calza, Gartner, and Sousa (2003), a possible explanation for an income elasticity above unity is that GDP might capture the effect of omitted variables, such as wealth, which are also relevant to explain loan demand.

${ }^{17}$ Since the simulation horizon covers 20 quarters, we set $T=20$ for the calculation of the expected credit margin.
} 
Figure 3: Loan Supply and Loan Demand Components
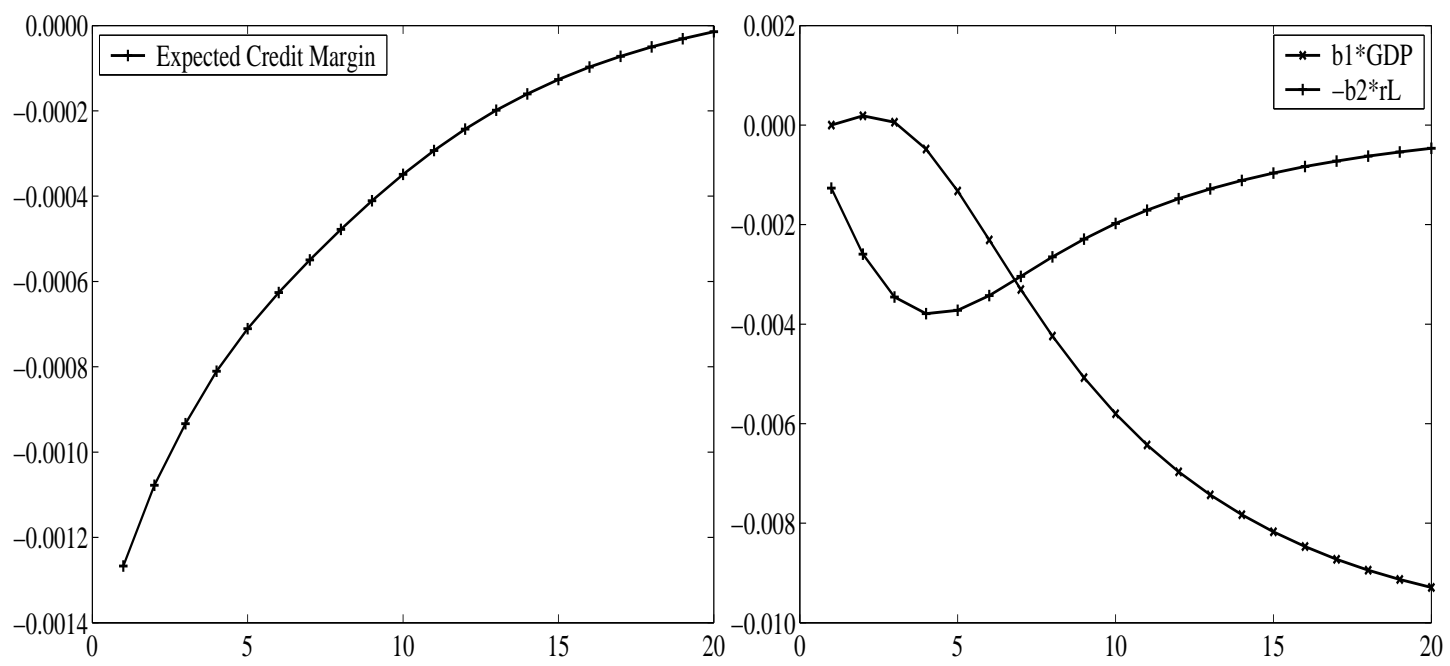

The findings suggest that loan supply by the banks declines with an expected fall in the credit margin after a monetary policy shock. The drop in the credit margin occurs instantly and bottoms out gradually. Loan demand declines with the decrease in the output level and the increase in the loan rate. The fall proceeds promptly despite the primary shift in the output level that is surpassed by the primary shift in the loan rate.

In conclusion, our findings imply that the adjustment of bank loans is characterized by the mutual drop in loan supply and loan demand following a monetary contraction. The decrease in loan supply emerges instantly and fades gradually, while the decrease in loan demand proceeds by degrees and lasts persistently.

\section{Concluding Remarks}

This paper has addressed the credit channel in Germany by using aggregate data. We have developed a stylized model of the banking firm in which banks decide on their loan supply in light of uncertainty about the future course of monetary policy. We have estimated the response of bank loans to a monetary policy shock taking into account the reaction of the output level and the loan rate. Using our model as a guide, we have evaluated the response of bank loans - i.e. disclosing the parts that can be attributed to loan supply and loan demand - by matching the theoretical impulse responses with the empirical impulse responses to a monetary policy shock.

Our findings suggest that the credit channel in Germany is working alongside 
the interest rate channel, which is consistent with De Bondt (2000), Holtemöller (2003), Hülsewig, Winker, and Worms (2004), Küppers (2001), Kakes and Sturm (2002) and Worms (2003), who draw similar conclusions. Our results imply that loan supply by the banks declines with an expected fall in the credit margin after a monetary policy shock, while loan demand drops with a fall in the output level and a raise in the loan rate. The decrease in loan supply occurs promptly and bottoms out gradually. The decrease in loan demand proceeds by degrees and continues persistently.

\section{Appendix}

\section{A A Stylized Model of the Banking Firm}

This appendix provides the steps used to derive a single bank's optimal loan supply and the loan market equilibrium. Define the lag operator by $H$ such that $H X_{t}=X_{t-1}$.

\section{A.1 Optimal Loan Supply of a Single Bank}

Optimal loan supply of a single bank is found by rewriting the first-order condition (6) as:

$$
\beta E_{t+j} L_{t+j+1}^{i}-(1+\beta) L_{t+j}^{i}+L_{t+j-1}^{i}=-a^{-1}\left(r_{t+j}^{L}-r_{t+j}^{M}\right),
$$

for $(j=0,1,2, \ldots)$, or:

$$
\beta\left[1-\frac{1+\beta}{\beta} H+\frac{1}{\beta} H^{2}\right] E_{t+j} L_{t+j+1}^{i}=-a^{-1}\left(r_{t+j}^{L}-r_{t+j}^{M}\right)
$$

for $(j=0,1,2, \ldots)$. Using the procedure established by Sargent $(1979$, pp. 197199), the left-hand side of equation (A.2) may be factored to obtain:

$$
\beta\left(1-\frac{1}{\beta} H\right)(1-H) E_{t+j} L_{t+j+1}^{i}=-a^{-1}\left(r_{t+j}^{L}-r_{t+j}^{M}\right),
$$

for $(j=0,1,2, \ldots)$.

The forward solution to equation (A.3) may be found by recognizing that $(1-\xi H)^{-1} E_{t+j} x_{t+j}=-\sum_{i=1}^{\infty}\left(\frac{1}{\xi}\right)^{i} E_{t+j} X_{t+j+i}$, if $\xi>1$ and $\left\{x_{t}\right\}$ is bounded (Sargent, 1979, p. 173). Here, $\xi=1 / \beta>1$ and $x_{t+j}=\left(r_{t+j}^{L}-r_{t+j}^{M}\right)$ is bounded, if the transversality condition is satisfied.

The transversality condition is given by $\lim _{T \rightarrow \infty} E_{t} \beta^{T}\left\{r_{T}^{L}-a\left(L_{T}^{i}-L_{T-1}^{i}\right)-\right.$ $\left.r_{T}^{M}\right\}=0$, where $T$ denotes the terminal period. According to Sargent (1979, pp. 197-200 and 335-336), the transversality condition holds if it is assumed 
that the stochastic processes for the interest rates, $\left\{r_{t+j}^{L}\right\}_{j=0}^{\infty}$, and $\left\{r_{t+j}^{M}\right\}_{j=0}^{\infty}$ are of exponential order less than $1 / \beta$., i.e. for some $K>0$ and $1<X<1 / \beta$,

$$
\left|E_{t} r_{t+j}^{L}\right|<K(X)^{t+j} \text { and }\left|E_{t} r_{t+j}^{M}\right|<K(X)^{t+j} .
$$

The forward solution to the bank's problem is (Sargent, 1979, p. 336):

$$
E_{t+j} L_{t+j+1}^{i}=L_{t+j}^{i}+(a \beta)^{-1} \sum_{s=1}^{\infty} \beta^{s} E_{t+j}\left(r_{t+j+s}^{L}-r_{t+j+s}^{M}\right),
$$

for $(j=0,1,2 \ldots)$. Next, expand the information set from $I_{t+j}$ to $I_{t+j+1}$ in (A.4), which is the information the bank has when taking the decision on $L_{t+j+1}$, and redefine the index from $t+j+1$ to $t+j$ (Cosimano, 1988, p. 135):

$$
L_{t+j}^{i}=L_{t+j-1}^{i}+a^{-1} \sum_{s=0}^{\infty} \beta^{s} E_{t+j}\left(r_{t+j+s}^{L}-r_{t+j+s}^{M}\right),
$$

for $(j=0,1,2 \ldots)$.

\section{A.2 Loan Market Equilibrium}

The loan market equilibrium is characterized by the equilibrium values of the loan level and the loan rate.

The equilibrium loan level (9) can be derived by means of the following steps. Multiplying equation (A.1) with $n$ and setting $j=0$ yields:

$$
\beta E_{t} L_{t+1}-(1+\beta) L_{t}+L_{t-1}=-n a^{-1}\left(r_{t}^{L}-r_{t}^{M}\right) .
$$

Next solve the demand for loans equation (8) for the loan rate:

$$
r_{t}^{L}=B_{1} y_{t}-B_{2} L_{t}
$$

where $B_{1}=b_{1} / b_{2}$ and $B_{2}=1 / b_{2}$, and substitute $r_{t}^{L}$ into equation (A.6), to obtain:

$$
\beta E_{t} L_{t+1}-\left(\beta+n a^{-1} B_{2}+1\right) L_{t}+L_{t-1}=-n a^{-1}\left(B_{1} y_{t}-r_{t}^{M}\right) .
$$

Applying the expectation lag operator yields:

$$
\beta\left[1-\frac{\psi}{\beta} H+\frac{1}{\beta} H^{2}\right] E_{t} L_{t+1}=-n a^{-1}\left(B_{1} y_{t}-r_{t}^{M}\right),
$$

where $\psi \equiv\left(\beta+n a^{-1} B_{2}+1\right)$. Now factor the left side of equation (A.9) using the procedure suggested by Sargent (1979, pp. 339-342):

$$
\left[1-\frac{\psi}{\beta} H+\frac{1}{\beta} H^{2}\right]=\left(1-\lambda_{1} H\right)\left(1-\lambda_{2} H\right),
$$


where $\lambda_{1}$ and $\lambda_{2}$ are positive characteristic roots, with $\lambda_{1}<1<1 / \beta<\lambda_{2}$.

Substituting expression (A.10) into (A.9) and applying the forward solution as in (A.4) yields:

$$
E_{t} L_{t+1}=\lambda_{1} L_{t}+n(a \beta)^{-1} \sum_{s=1}^{\infty} \lambda_{2}^{-s} E_{t}\left(B_{1} y_{t+s}-r_{t+s}^{M}\right) .
$$

Equation (A.11) can be rewritten by expanding the information set from $I_{t}$ to $I_{t+1}$, which gives:

$$
L_{t}=\lambda_{1} L_{t-1}+\lambda_{1} n a^{-1} \sum_{s=0}^{\infty} \lambda_{2}^{-s} E_{t}\left(B_{1} y_{t+s}-r_{t+s}^{M}\right),
$$

after changing the index from $t+1$ to $t$ and recognizing that $\lambda_{1}=1 /\left(\beta \lambda_{2}\right)$.

The equilibrium loan rate (10) is found by inserting equation (A.12) into equation (A.7) and rearranging terms.

\section{B Data Base}

All the data used for the VECM analysis is taken from the German Bundesbank (www.bundesbank.de) and the German Federal Statistical Office (www.destatis.de).

1. LOANS: Loans to domestic firms and private households (all banks), seasonally unadjusted. German Bundesbank: PQA350; deflated with the Consumer Price Index: UUFA01.

2. GDP: Real German GDP in prices from 1995, seasonally unadjusted. German Federal Statistical Office.

3. Loan rate $r^{L}$ : Average of the rate on mortgage loans and the rates of current account loans. German Bundesbank: SU0001, SU0004 and SU0049. Converted into quarterly data.

4. Short-term interest rate $r^{M}$ : Three-month money market rate, Frankfurt/Main, monthly averages, German Bundesbank: SU0107. Converted into quarterly data.

Figure 4 displays the time series in levels and first differences. 
Figure 4: Time Series in Levels and First Differences
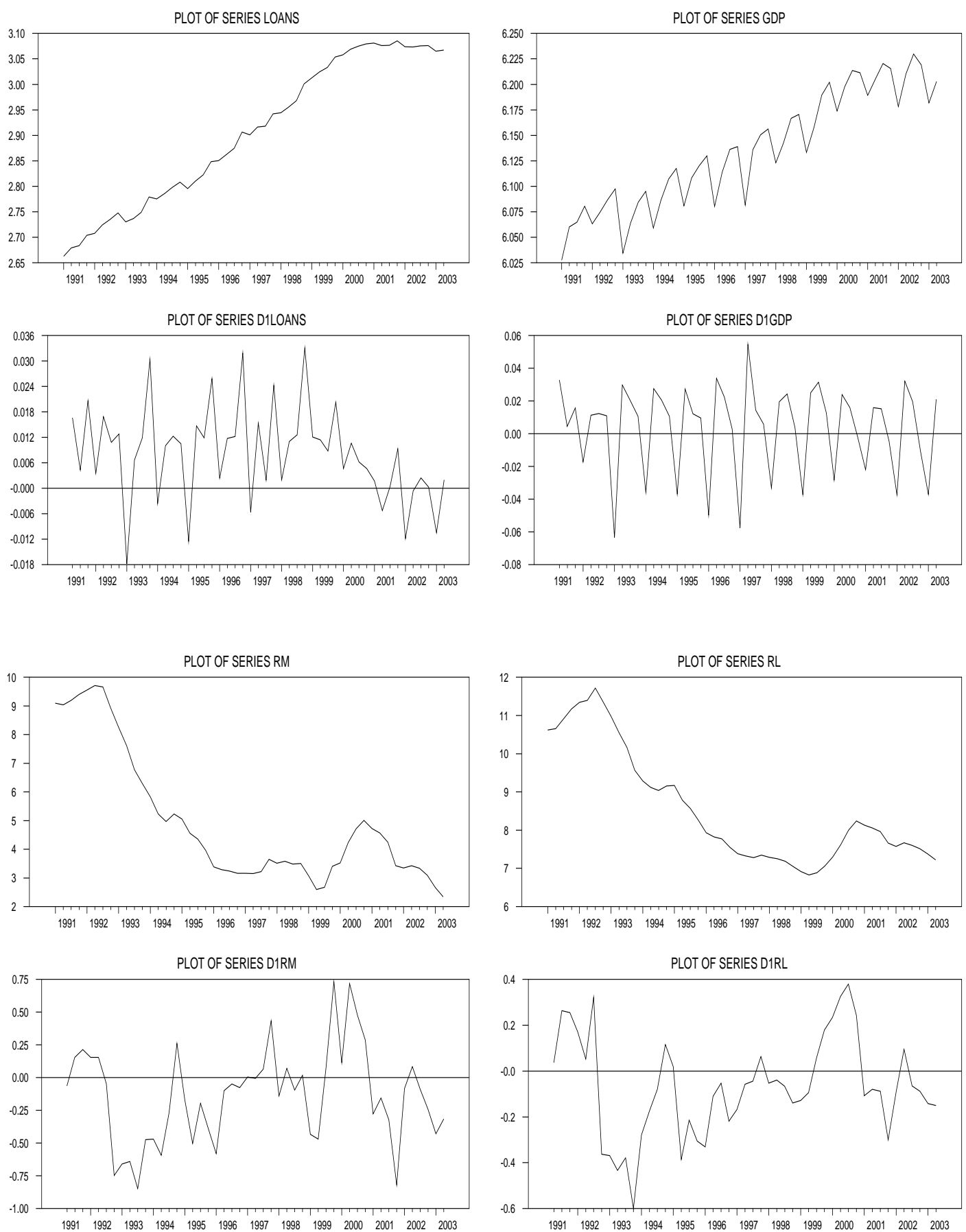


\section{References}

Baltensperger, E. (1980): "Alternative Approaches to the Theory of the Banking Firm," Journal of Monetary Economics, 6, 1-37.

Barran, F., V. Coudert, and B. Mojon (1997): "The Transmission of Monetary Policy in the European Countries," in European Monetary Policy, ed. by S. C. Collignon, pp. 81-111, London.

Bernanke, B. S., And A. S. Blinder (1992): "The Federal Fund Rate and the Channels of Monetary Transmission," American Economic Review, 82, 901921.

Bernanke, B. S., And M. Gertler (1995): "Inside the Black Box: The Credit Channel of Monetary Policy Transmission," Journal of Economic Perspectives, 9(4), 27-48.

Bofinger, P. (2001): Monetary Policy: Goals, Institutions, Strategies, and Instruments. Oxford University Press, New York.

Calza, A., C. Gartner, and J. Sousa (2003): "Modelling the Demand for Loans to the Private Sector in the Euro Area," Applied Economics, 35(1), 107117.

Calza, A., M. Manrique, and J. Sousa (2003): "Aggregate Loans to the Euro Area Private Sector," Working Paper Series 202, European Central Bank.

Cecchetti, S. G. (1995): "Distinguishing Theories of the Monetary Transmission Mechanism," Federal Reserve Bank of St. Louis Review, 77(3), 83-97.

Christiano, L. J., M. Eichenbaum, and C. Evans (2004): "Nominal Rigidities and the Dynamic Effects of a Shock to Monetary Policy," Journal of Political Economy, forthcomming.

Cosimano, T. F. (1988): "The Banking Industry und Uncertain Monetary Policy," Journal of Banking and Finance, 12, 117-139.

De Bondt, G. J. (2000): Financial Structure and Monetary Transmission in Europe. Edward Elgar, Cheltenham, UK.

Deutsche Bundesbank (2004): "The new MFI Interest Rate Statistics Methodology for Collecting the German Data," Monthly Report, 1, 47-62. 
Ehrmann, M. (2004): "Firm Size and Monetary Policy Transmission: Evidence from German Business Survey Data," in Ifo Survey Data in Business Cycle and Monetary Policy Analysis, ed. by J. E. Sturm, and T. Wollmershäuser, pp. 145-172, Heidelberg. Physica Verlag.

Ehrmann, M., And A. Worms (2004): "Bank Networks and Monetary Policy Transmission," Journal of the European Economic Association, forthcomming.

Elyasiani, E., K. J. Kopecky, and D. van Hoose (1995): "Costs of Adjustment, Portfolio Seperation, and the Dynamic Behavior of Bank Loans and Deposits," Journal of Money, Credit and Banking, 27(4), 955-974.

Fase, M. M. G. (1995): "The Demand for Commercial Bank Loans and the Lending Rate," European Economic Review, 39, 99-111.

Freixas, X., And J.-C. Rochet (1997): Microeconomics of Banking. MIT Press Cambridge, Massachusetts, Massachusetts.

Gertler, M., and S. Gilchrist (1993): "The Role of Credit Market Imperfections in the Monetary Transmission Mechanism: Arguments and Evidence," Scandinavian Journal of Economics, 95(1), 43-64.

Gilchrist, S. G., And E. ZaKrajSeK (1995): "The Importance of Credit for Macroeconomic Activity: Identification through Heterogenity," in Is Bank Lending important for the Transmission of Monetary Policy?, ed. by J. Peek, and E. S. Rosengreen, vol. 39 of Federal Reserve Bank of Boston Conference Series, pp. 129-158, Boston.

Holtemöller, O. (2003): "Further VAR Evidence for the Effectiveness of a Credit Channel in Germany," Applied Economics Quarterly, 49(4), 359-381.

Hubbard, R. G. (1995): "Is There a Credit Channel for Monetary Policy?," Federal Reserve Bank of St. Louis Review, 77(3), 63-77.

Hülsewig, O., P. Winker, And A. Worms (2004): "Bank Lending in the Transmission of Monetary Policy: A VECM Analysis for Germany," Jahrbücher für Nationalökonomie und Statistik, 224(5), 511-529.

Johansen, S. (1995): Likelihood-Based Inference in Cointegrated Vector Autoregressive Models. Oxford University Press, Oxford.

Johansen, S., And K. Juselius (1990): "Maximum Likelihood Estimation and Inference on Cointegration - With Applications to the Demand for Money," Oxford Bulletin of Economics and Statistics, 52(2), 169-210. 
KAKes, J. I. (2000): Monetary Transmission in Europe. Edward Elgar, Celtenham.

Kakes, J. I., And J.-E. Sturm (2002): "Monetary Policy and Bank Lending: Evidence from German Banking Groups," Journal of Banking and Finance, 26, 2077-2092.

Kashyap, A. K., and J. C. Stein (2000): "What do a Million Observations on Banks Say About the Transmission of Monetary Policy?," American Economic Review, 90(3), 407-428.

Kishan, R. P., and T. P. Opiela (2000): "Bank Size, Bank Capital, and the Bank Lending Channel," Journal of Money, Credit, and Banking, 32(1), $121-141$.

Klein, M. A. (1971): "A Theory of the Banking Firm," Journal of Money, Credit and Banking, 3, 205-218.

Küppers, M. (2001): "Curtailing the Black Box: German Banking Groups in the Transmission of Monetary Policy," European Economic Review, 45(10), 19071930.

Mackinnon, J. G., A. A. Haug, and L. Michelis (1999): "Numerical Distribution Functions of Likelihood Ratio Tests for Cointegration," Journal of Applied Econometrics, 14(5), 563-577.

Mitusch, K., And D. Nautz (2001): "Interest Rate and Liquidity Risk Management and the European Money Supply Process," Journal of Banking and Finance, 25(11), 2089-2101.

Mojon, B., and G. Peersman (2003): "A VAR Description of the Effects of Monetary Policy in the Individual Countries of the Euro Area," in Monetary Policy Transmission in the Euro Area, ed. by I. Angeloni, A. Kashyap, and B. Mojon, pp. 56-74, Cambridge. Cambridge University Press.

Oliner, S. D., and G. D. Rudebusch (1995): "Is there a Bank Lending Channel for Monetary Policy?," Federal Reserve Bank of San Francisco Economic Review, 2, 3-20.

Rotemberg, J. J., And M. Woodford (1998): "An Optimization-Based Econometric Framework for the Evaluation of Monetary Policy: Expanded Version," Technical Working Paper 233, National Bureau of Economic Research.

Sargent, T. J. (1979): Macroeconomic Theory. Academic Press, New York. 
Smets, F., And R. Wouters (2002): "Openness, Imperfect Exchange Rate Pass-Through and Monetary Policy," Journal of Monetary Economics, 49, 947981.

Söderlind, P. (1999): "Solution and Estimation of RE Macromodels with Optimal Policy," European Economic Review, 43, 813-823.

Von Kalckreuth, U. (2003): "Monetary Transmission in Germany: New Perspectives on Financial Constraints and Investment Spending," in Monetary Policy Transmission in the Euro Area, ed. by I. Angeloni, A. Kashyap, and B. Mojon, pp. 173-186, Cambridge. Cambridge University Press.

Worms, A. (2003): "The Reaction of Bank Lending to Monetary Policy Measures in Germany," in Monetary Policy Transmission in the Euro Area, ed. by I. Angeloni, A. Kashyap, and B. Mojon, pp. 179-198, Cambridge. Cambridge University Press. 


\section{CESifo Working Paper Series}

(for full list see www.cesifo.de)

1317 Attila Ambrus and Rossella Argenziano, Network Markets and Consumers Coordination, October 2004

1318 Margarita Katsimi and Thomas Moutos, Monopoly, Inequality and Redistribution Via the Public Provision of Private Goods, October 2004

1319 Jens Josephson and Karl Wärneryd, Long-Run Selection and the Work Ethic, October 2004

1320 Jan K. Brueckner and Oleg Smirnov, Workings of the Melting Pot: Social Networks and the Evolution of Population Attributes, October 2004

1321 Thomas Fuchs and Ludger Wößmann, Computers and Student Learning: Bivariate and Multivariate Evidence on the Availability and Use of Computers at Home and at School, November 2004

1322 Alberto Bisin, Piero Gottardi and Adriano A. Rampini, Managerial Hedging and Portfolio Monitoring, November 2004

1323 Cecilia García-Peñalosa and Jean-François Wen, Redistribution and Occupational Choice in a Schumpeterian Growth Model, November 2004

1324 William Martin and Robert Rowthorn, Will Stability Last?, November 2004

1325 Jianpei Li and Elmar Wolfstetter, Partnership Dissolution, Complementarity, and Investment Incentives, November 2004

1326 Hans Fehr, Sabine Jokisch and Laurence J. Kotlikoff, Fertility, Mortality, and the Developed World's Demographic Transition, November 2004

1327 Adam Elbourne and Jakob de Haan, Asymmetric Monetary Transmission in EMU: The Robustness of VAR Conclusions and Cecchetti's Legal Family Theory, November 2004

1328 Karel-Jan Alsem, Steven Brakman, Lex Hoogduin and Gerard Kuper, The Impact of Newspapers on Consumer Confidence: Does Spin Bias Exist?, November 2004

1329 Chiona Balfoussia and Mike Wickens, Macroeconomic Sources of Risk in the Term Structure, November 2004

1330 Ludger Wößmann, The Effect Heterogeneity of Central Exams: Evidence from TIMSS, TIMSS-Repeat and PISA, November 2004

1331 M. Hashem Pesaran, Estimation and Inference in Large Heterogeneous Panels with a Multifactor Error Structure, November 2004 
1332 Maarten C. W. Janssen, José Luis Moraga-González and Matthijs R. Wildenbeest, A Note on Costly Sequential Search and Oligopoly Pricing, November 2004

1333 Martin Peitz and Patrick Waelbroeck, An Economist's Guide to Digital Music, November 2004

1335 Lutz Hendricks, Why Does Educational Attainment Differ Across U.S. States?, November 2004

1336 Jay Pil Choi, Antitrust Analysis of Tying Arrangements, November 2004

1337 Rafael Lalive, Jan C. van Ours and Josef Zweimueller, How Changes in Financial Incentives Affect the Duration of Unemployment, November 2004

1338 Robert Woods, Fiscal Stabilisation and EMU, November 2004

1339 Rainald Borck and Matthias Wrede, Political Economy of Commuting Subsidies, November 2004

1340 Marcel Gérard, Combining Dutch Presumptive Capital Income Tax and US Qualified Intermediaries to Set Forth a New System of International Savings Taxation, November 2004

1341 Bruno S. Frey, Simon Luechinger and Alois Stutzer, Calculating Tragedy: Assessing the Costs of Terrorism, November 2004

1342 Johannes Becker and Clemens Fuest, A Backward Looking Measure of the Effective Marginal Tax Burden on Investment, November 2004

1343 Heikki Kauppi, Erkki Koskela and Rune Stenbacka, Equilibrium Unemployment and Capital Intensity Under Product and Labor Market Imperfections, November 2004

1344 Helge Berger and Till Müller, How Should Large and Small Countries Be Represented in a Currency Union?, November 2004

1345 Bruno Jullien, Two-Sided Markets and Electronic Intermediaries, November 2004

1346 Wolfgang Eggert and Martin Kolmar, Contests with Size Effects, December 2004

1347 Stefan Napel and Mika Widgrén, The Inter-Institutional Distribution of Power in EU Codecision, December 2004

1348 Yin-Wong Cheung and Ulf G. Erlandsson, Exchange Rates and Markov Switching Dynamics, December 2004

1349 Hartmut Egger and Peter Egger, Outsourcing and Trade in a Spatial World, December 2004

1350 Paul Belleflamme and Pierre M. Picard, Piracy and Competition, December 2004 
1351 Jon Strand, Public-Good Valuation and Intrafamily Allocation, December 2004

1352 Michael Berlemann, Marcus Dittrich and Gunther Markwardt, The Value of NonBinding Announcements in Public Goods Experiments: Some Theory and Experimental Evidence, December 2004

1353 Camille Cornand and Frank Heinemann, Optimal Degree of Public Information Dissemination, December 2004

1354 Matteo Governatori and Sylvester Eijffinger, Fiscal and Monetary Interaction: The Role of Asymmetries of the Stability and Growth Pact in EMU, December 2004

1355 Fred Ramb and Alfons J. Weichenrieder, Taxes and the Financial Structure of German Inward FDI, December 2004

1356 José Luis Moraga-González and Jean-Marie Viaene, Dumping in Developing and Transition Economies, December 2004

1357 Peter Friedrich, Anita Kaltschütz and Chang Woon Nam, Significance and Determination of Fees for Municipal Finance, December 2004

1358 M. Hashem Pesaran and Paolo Zaffaroni, Model Averaging and Value-at-Risk Based Evaluation of Large Multi Asset Volatility Models for Risk Management, December 2004

1359 Fwu-Ranq Chang, Optimal Growth and Impatience: A Phase Diagram Analysis, December 2004

1360 Elise S. Brezis and François Crouzet, The Role of Higher Education Institutions: Recruitment of Elites and Economic Growth, December 2004

1361 B. Gabriela Mundaca and Jon Strand, A Risk Allocation Approach to Optimal Exchange Rate Policy, December 2004

1362 Christa Hainz, Quality of Institutions, Credit Markets and Bankruptcy, December 2004

1363 Jerome L. Stein, Optimal Debt and Equilibrium Exchange Rates in a Stochastic Environment: an Overview, December 2004

1364 Frank Heinemann, Rosemarie Nagel and Peter Ockenfels, Measuring Strategic Uncertainty in Coordination Games, December 2004

1365 José Luis Moraga-González and Jean-Marie Viaene, Anti-Dumping, Intra-Industry Trade and Quality Reversals, December 2004

1366 Harry Grubert, Tax Credits, Source Rules, Trade and Electronic Commerce: Behavioral Margins and the Design of International Tax Systems, December 2004

1367 Hans-Werner Sinn, EU Enlargement, Migration and the New Constitution, December 2004 
1368 Josef Falkinger, Noncooperative Support of Public Norm Enforcement in Large Societies, December 2004

1369 Panu Poutvaara, Public Education in an Integrated Europe: Studying to Migrate and Teaching to Stay?, December 2004

1370 András Simonovits, Designing Benefit Rules for Flexible Retirement with or without Redistribution, December 2004

1371 Antonis Adam, Macroeconomic Effects of Social Security Privatization in a Small Unionized Economy, December 2004

1372 Andrew Hughes Hallett, Post-Thatcher Fiscal Strategies in the U.K.: An Interpretation, December 2004

1373 Hendrik Hakenes and Martin Peitz, Umbrella Branding and the Provision of Quality, December 2004

1374 Sascha O. Becker, Karolina Ekholm, Robert Jäckle and Marc-Andreas Mündler, Location Choice and Employment Decisions: A Comparison of German and Swedish Multinationals, January 2005

1375 Christian Gollier, The Consumption-Based Determinants of the Term Structure of Discount Rates, January 2005

1376 Giovanni Di Bartolomeo, Jacob Engwerda, Joseph Plasmans, Bas van Aarle and Tomasz Michalak, Macroeconomic Stabilization Policies in the EMU: Spillovers, Asymmetries, and Institutions, January 2005

1377 Luis H. R. Alvarez and Erkki Koskela, Progressive Taxation and Irreversible Investment under Uncertainty, January 2005

1378 Theodore C. Bergstrom and John L. Hartman, Demographics and the Political Sustainability of Pay-as-you-go Social Security, January 2005

1379 Bruno S. Frey and Margit Osterloh, Yes, Managers Should Be Paid Like Bureaucrats, January 2005

1380 Oliver Hülsewig, Eric Mayer and Timo Wollmershäuser, Bank Loan Supply and Monetary Policy Transmission in Germany: An Assessment Based on Matching Impulse Responses, January 2005 